\title{
THE LIFE PROBLEM IN WAGNER'S DRAMAS
}

\author{
By WILHELM PETERSON-BERGER ${ }^{1}$
}

$\mathrm{T}$

HE main rootstock from which Wagner's art springs is the Greek music drama, which was kept alive, by means of the words; through a long winter's sleep, until the spring of a new era, the time of the Renaissance. Then it became the object of a culturally conscious and historically antique attempt at revival, until finally it was transplanted by Richard Wagner, and given new sap and new growing power by the ingrafting of shoots from Germanic myths, music and song.

The transplanting of a rootstock from one soil to another, would naturally be impossible, unless both localities offered the same nourishment. Such nourishment is to be found in the problems which the tragic-humorous conception of life, of necessity both creates and brings to a solution in real life, as well as in its most artistic of mirrors, the music drama.

In truth, every attack on life, every obstacle which interferes with the continuity of life in its fullest and richest form, involves a life problem. In its typical, and for man its most significant form, this problem always appears as a conflict between opposing life factors, in particular between the individual and the superindividual, the private and public interest, the genius and the people, the ego and the world.

Conflicts may occur during processes of change, but in the main they arise in two ways: either directly, as when the individual, in a demand for his real or imagined rights, sets up his strength and his superiority against the world, which he wholly or in part ignores; or indirectly, ss when the individual so entirely and completely yields to a certain superindividual instinct that everything else is ignored. In the first case, the opposition of the individual to the world from the standpoint of life may or may not be justifiable. In the second, the right is usually on the side of the world, the disturbed harmony of life.

1 Wilhelm Peterson-Berger's compositions are at last gredually entering into American musical lifa Not $w^{\circ}$ his writinga; reseon enough for presenting bere b? eqreement the third chepter in his book, "Richard Wagner mom .rulturfuretedion" Stoctholm, 1913. $-E d$. 
In real life these conflicts are solved according to the tragichumorous conception of life, in general justly, that is, in conformity to the laws of life; but very rarely in a way sufficiently logical and free from accidental contingencies, so that the conformance to the laws of life and justice may be plainly perceived. It is therefore the biological mission of tragic works of art to supplement and support the empirical realities of life by putting them on trial. If the outcome of the conflict is uncertain, the man with artistic feeling makes an appeal in error. The stage is the court of justice, and tragedy the spokesman, who conducts the trial between the ego and the world, in conformance to the highest laws governing the exigencies of life.

By means of this legal procedure, conflicts are summarized and reduced to typical life problems. The significance of the life problem for tragic art work or drama, is therefore the greatest imaginable. It constitutes the strongest hold of tragedy on reality, and is its biological justification for being.

In this connection, we have eliminated from our investigation all artificial drama that is based, not on real life problems, but on arbitrarily constructed "theater problems," or problems imitating life which, although they may possess a skillfully manufactured mechanical power to hold the imagination, never have the vital force necessary to awaken and elevate the sensibilities.

Aristotle describes the effect of the Greek music drama on the spectator as follows: The drama awakens within the spectator feelings of sympathy and awe, and thence by means of these emotions, brings about a "purification" of his being.

Refraining for the time from investigating more closely the true import of this view as a whole, let us turn our attention to the first statement: Tragedy awakens sympathy and awe. It is clear that this must come about through the incarnation of humanity in the life problem itself, and its exemplification in the dramatically living characters.

In this respect we are able to subscribe completely to Aristotle's view, even though we may not fully admit the present force of his terminology. But in order to feel sympathy and awe in the presence of an imitation of life, one must first be able to recognize the problem. No matter how powerfully a stage character may act, if we do not understand his emotion, his suffering and its cause, then we have no perception that the life problem is real and that its solution concerns us.

On the other hand, one must not assume that all dramatically expressed life problems, or those capable of being so expressed, 
must necessarily be perceived immediately as such by all spectators. Individual life experiences vary to the greatest extent, both as to nature and circumstances. But nevertheless, analogies do erist, on the basis of which the great mass of spectators may be divided into larger or smaller groups, according to the number and kind of life problems they are able to recognize. The largest group, very naturally, is made up of those whose experience embraces only the most universal phenomena, those common alike to high and low, rich and poor, man and woman, whether exceptional or ordinary. And the dramatic poet is not unwise who tries to find out beforehand how large a public will be able to comprehend the life problem of his drame in its simplest elemental form, and how its presentation and solution must be worked out in order to get hold of the public, large or amall, that he has in view.

Therefore, the artist who addresses himself to an entire people-as the true music dramatist does, in general-must avoid all problems, for the understanding of which only a limited number may possess the necessary experience and receptivity. He must, as Richard Wagner expressed it, concern himself alone with the "purely human," that is to say, in the broadest sense of the term, with that which is typically human.

If now, after these general observations, we attempt to find out how far and in what way Wagner himself, in his artistic work, applied this rule of the "purely human" to his life problem, we at first get the unfavorable impression that his productions in this respect exhibit great diversity and inconsistency. In many of his dramas the characters, as for instance the title roles in "The Flying Dutchman" and "Lohengrin," and nearly all the figures in "The Ring of the Nibelung," are purely legendary beings with powers, faculties, and theories of life more or less contradictory to the reality as we know it. They may therefore, at best, be looked upon as poetic symbols of the universal, of the general relations and superindividual factors of life, but not as representative of the individual, the single living human being.

And yet, in this trial between the individual and superindividual forces of life, which true drama may be said to portray, it is naturally indispensable that the human being should be presented as faithfully and truthfully as possible. A character whose actions and theories of life show him to be free from all constraint of fact, can not be truly tragic. On the contrary, however, a figure which wears a mythological or romantically fantastic form, may be tragic if its desires and manifestations of will are humanly limited and humanly true. Such a figure is that of the most 
wonderful, perhaps, of all the heroes of Attic tragedy, the Titan Prometheus, who steals the fire from the selfish and power-loving gods, in order to elevate the human race, and who for this noble crime, is made to suffer the most dreadful tortures.

Meanwhile, if we continue our investigation of the life problem in Wagner's dramas from this standpoint, and direct our attention to the chief characters that are presented as real beings with human limitations, we shall soon come to a more harmonious and favorable result.

Let us turn then first, appropriately, to that one of Wagner's tragic compositions, in which all the characters are human beings. There is only one such, "Tristan and Isolde." In this drama we find ourselves, in spite of the mythical origin of the theme, on a foundation of reality. The only scene that has any connection with legendary fantasy, is that of the charmed drink in the first act. The supernatural power of the drink is not represented by the poet as really existing, but he allows the personages of the drama to be convinced of its power in order to base on this conviction thoir conception of the proposed life problem.

What, then, is this life problem? The legend, the theme, the characters of this much-celebrated story allow only one answer: love, the superindividual instinct for the preservation of life, appearing as the destroyer of the indioidual-in other words: the destruction of life through eroticism, a situation created and enhanced by the biological superiority of fervent beings, by their strength of feeling and spiritual inflammability. One is temptred not to recognize this as a tragic life problem, but rather as a pathologically abnormal situation-and yet we read, time and again, accounts of double erotic suicide which likewise prove that the longing of erotic love may assail and destroy one who is too weak to withstand the strain.

The only thing that can be urged against this life problem as a basis for tragic drama, is that its solution is known from the beginning. It leads to a tragedy of pure fate, where helpless individuals are crushed by blind, inexorable forces. Nor is the conflict of the kind which we have just designated as immediate. It arises, not by direct opposition of the individual to the super or exceptional individual, but comes about indirectly from the fact that the individual too unreservedly and completely yields to one superindividual instinct - in this case, love - at the expense of everything else. That the tragedy which thus develops from such indirect conflicts, and above all from the erotic problem, is less strong, less clearly significant of life, and less convincing in its 
artistic results than the tragedy of immediate conflict, we may now be able to see through this example.

Wagner declared "Tristan" to be in every respect, both as to words and music, his most personal, typical, and most perfectly executed work. As to the music, this has always been acknowledged. The glowing passion, the immeasurable pathos, all the unwearied striving for expression through the entire scale of erotic moods, from transports of joy to longing for death; all this, from the beginning, has been looked upon less as the necessary elucidation of a choice poetic theme, than as the direct outpouring of the poet's inner soul, a revelation of the composer's personality.

But the peculiar note in this music is that which-if at the same time weaker and more intermittent and conventional-prefigures the themes of all his other dramas, the note which here in "Tristan" unveils the mystery and reveals itself as oroticiom.

And now, a misgiving seizes us. If Wagner's most characteristic and most personal note attained its fullest expression in this work, which treats of eroticism as a tragic problem, may it not be possible that this same note, ringing out more or less clearly in his other works, is but the expression of the same problem?

The answer can not be other than in the affirmative. For this thought not only suddenly opens the way for a uniform and comprehensive survey of the multitude of questions and phenomena connected with Wagner's work, but what is more important, it gives a psychological explanation of his peculiar art and its influence on auditors of different kinds.

Wagner, a music drama eroticl If we undertake to investigate the tragic in his dramas with the help of this formula, its power to explain, its manifest character of key-word to the riddle not yet fully solved, will not fail to strike us. And in order to approve of this formula, it is not necessary to side with the present scientific tendency to explain, on principle, all manifestations of human soul life as directly resultant from erotic and sexual relations.

In "The Flying Dutchman," it is easy to show, under all circumstances, that the purely human tragedy does not lie with the masculine title role, but with the feminine character, Senta. Her heart is the heart of the drama. This peculiar, though by no means unfamiliar feminine eroticism, first finds expression in infinite compassion for an unfortunate being, unknown except by hearsay and as pictured by the imagination, and in a fervent longing for self-sacrifice in his behalf. Afterward, at the first meeting, this feeling is transformed into a passion of blissfully exultant devotion, which is revealed in all its intensity as soon as occasion 
offers, when the necessary solution is brought about by sudden, voluntary death.

This feminine eroticism is a typical life problem of the same sort as that in "Tristan," and its humanness, which counteracts the symbolic legendary fantasy of the Dutchman, forms a connecting link with reality.

"Lohengrin" exhibits, in this respect, a striking gimilarity to "The Flying Dutchman." Even here, the chief masculine role is filled by a symbolized legendary character which, however, is as radiantly bright and beautiful as that of the Dutchman is oppressively dark and somber.

Likewise, here also the real tragedy is to be found in Elsa, the feminine counterpart, so humanly portrayed. Like Senta, she is an erotic visionary and has seen her lover in her dreams. But hor tragedy lies in the conflict arising between an individual element-a sense of her own worth awakened during the course of the drama-and a superindividual love, with which, furthermore, gratitude has entered into an alliance.

Thus, the life problem of this drama also, the note of reality which appeals most strongly to the spectator, is the question, to what lengths a woman's love can go in submission and selfrenunciation. And since the conflict between the individual and the world is here direct, the tragedy of the answer is only so much the greater.

The presentation and the development of the problem, which here very naturally take on the character of a test, are meanwhile carried out with something of the directness of the folk-tale. Lohengrin's charge to his loved one not to seek to learn who he is, as in the beautiful original of this myth, the late Greek Eros and Psyche legend, acquires human significance only through poeticsymbolic interpretation, and has, in reality, more the character of a fanciful and pleasing theater problem, than that of an immediate life problem.

The fundamental significance which eroticism possesses for the principal theme in the tetralogy of "The Nibelung Ring," is immediately brought out in the first scene of the prelude, "The Rhinegold." Whole movements are nothing but a demonstration, half musical, half philosophical, of the misfortunes and the -çurse which the forswearing of love-in every sense of the term-brings upon the world; while in the last scene of the last drama, this same love is represented as the only force which has the power to remove the curse and restore peace to the world. 
And in each separate drama the love motif is everywhere the central theme. In "The Rhinegold" it appears as Freya, the goddess of love; in "The Valkyr," as the tragic and gloomy fate of the twin couple, Siegmund and Sieglinde; in the succeeding play of "Siegfried," as the bliss of the hero and the maiden he awakens; and finally, in "The Twilight of the Gods," it appears first as fiendish enchantment, and lastly as a pantheistic redemption of the world.

But few purely human life problems are solved in "The Ring of the Nibelung," although the dramatic development often touches them closely. The whole is a sort of grandiose morality in the form of tragic drams, with the chief character, Wotan himself, in his thirst for power, appearing more as an allegorical than as a truly tragic figure. And practically the same thing holds true with all the other more or less mythical, supernatural, and symbolical characters.

Wagner's last work, "Parsifal," and "The Ring of the Nibelung," among other things have this in common, that they both treat of the renunciation of erotic love, although from standpoints almost diametrically opposed. While in the tetralogy this renunciation is the root of all evil, in "Parsifal," on the contrary, it is the most typical expression of the highest and noblest efforts. of humanity and spiritualized chivalry to attain purity and truth.

That the renunciation of erotic love under certain conditions may spring from the individualistic instinct for the preservation of life, and may thus involve a life problem in the sense which we now apply to the term, is not a new idea. . Even in modern Swedish literature are to be found many forceful expressions for anti-erotic moods. The renunciation of eroticism, which indeed most commonly occurs in connection with old age and a general sublimation and cooling of passions, appears not merely as a fundamental idea in the doctrines of purity among the more advanced religions, but is seen among both primitive and civilized races. Especially characteristic is the position which eroticism holds among races that are distinguished by a tragic-humorous conception of life.

Among the Greeks of the Attic tragedy, whose Eros cult we like to picture in such glowing terms, erotic love was looked upon with something of a mixture of mild disdain and fear, concealed beneath that genuinely beautiful Hellenic attitude of poetic worship. The Greeks, perhaps more than many races of later times, were conscious of the dangers involved in this life force, both for the individual and for the race, unless it were restrained by other instincts, by reason or experience. 
In the eye of the tragically wise Greek, therefore, eroticism appeared as something foolishly effeminate and unmanly. Nor did it play any role in tragedy until the time of Euripides and the decadence. Not until the masculine tragic conception of life had disappeared from the ancient world, did the true Greek Eros cult begin, effeminate, untragic, and Alexandrian to the last degree. During the period of its highest development, the life problems of tragedy were purely individualistic and distinctly masculine, as in the works of Eschylos and Sophocles. The roles were chiefly masculine-or feminine, with masculine strength of mind and fortitude - and the audience addressed was, above all, masculine.

This knowledge of the dangers of erotic intorication, and this disdain for the effeminacy of love, may be seen still more plainly among the Germanic races during their earlier stages of civilization: In 8 world where the struggle for existence so often assumed such terrible forms, it was soon learned that the acts which resulted from the delirium of erotic excitement were to the highest degree fatal to the continuance of life, both of the individual and of the racoand also, that the instinct which looked after this continuance must, like every other natural force, be caught, tamed, and guided, in order that it might fulfil its mission in the best possible way, without injury or harm to itself.

This masculine, unromantic conception of the nature of love early developed among the Teutons into a stern anti-erotic system of morals, which Christianity only seemingly and in part set aside. In the opposition of the new religion to sensuality, namely, is to be found a point of contact through which the instinctive, inherited conceptions were passed on and fused with the craving of medieval Christianity for chastity and purity.

But the Teuton's inner life of sentiment and feeling, only half expressed through the changes of centuries, continued to live, though inconspicuously, along with his poise of mind and strong sense of wholesomeness. And it was this inner life, turned back on itself and combined with certain moral ideals, which created in his soul a sort of modesty, a shy reluctance to exhibit or give expression to any strong feeling, and in particular to any erotic sentiment. Yet under the double constraint of the moral law and this noble, instinctive modesty, his inner life but grew in strength until at last it found expression in a form in which all contradictions could be united-the form of art. The German minnelied, as well as similar compositions in other lands, is an unmistakable manifestation of this intensity of feeling and repletion of moods accumulated through the centuries. 
Meanwhile, through the union of the matured ideal of true Germanic chivalry with the religious idea of the Christian church, the eroticism of the minnelied soon reached a point where it lost or surrendered all self-control. In spite of its origin in an instinct for life preservation, it therefore grew away-in part through outer influences-from nature and reality, and took on a form of romanticism of the most insidious kind, devoting itself, in a way originally foreign to the Teutons, to a platonic-fantastic morship of woman. This very naturally had a strong influence on woman's conception of love, especially the woman of the higher class, who instinctively sought to preserve purity of morals and thought. And thus, through her was established this socially aristocratic, religio-romantic conception of love among all classes of society, as in reality it still exists to-day.

But the unrestrained, natural force of love is not to be done away with in this fashion. It is continually bursting its fetters, and each of its encounters with the religio-romantic conception is the occasion of a tragic conflict.

This is the origin of the life problem in "Tannhkuser," from the erotic standpoint possibly the most interesting of all Wagner's works-not excepting "Tristan." Like all erotic conflicts, this is not wholly typical and direct, a conflict between the individual and the world, but rather is indirect. A superindividual instinct, an elemental love, takes possession of the individual, and thus brings him into conflict with another superindividual power, that of the anti-erotic instinct of protection transformed into a religioromantic enthusiasm for love.

Tannhiuser is a hot-blooded poet, and as such is open to the influence of everything natural and human, and is independent of class opinions and conventions. But as a nobleman he still shares the views of his class, and is susceptible to the influence of religious romanticism. Moreover, opposition and conflict exist in his own being from the beginning; while in "Tristan," according to their own declaration, the chief characters in reality stand in opposition only to the outer world. This is the reason why the eroticism of "Tannhbuser" in the end proves more interesting psychologically, even though the tragedy is not sufficiently individualistic to be thoroughly convincing and illuminating.

Tannhliuser is not a strong, invincible hero, but evidently he never has possessed the power of moulding the contradictions of his soul into a spiritual whole, just as little as he has had any conception that alongside of the poetic-elemental and the feminine-romantic conceptions of love, there is to be found a third, 
endlessly more significant-the masculine, anti-erotic, genuinely tragic conception, in character proud, truly pure, valiant and ideal. But Tannhliuser's ignorance in this case rests with Wagner. The erotic in the drama, as well as his parallel in reality, was foreign to the writers of the Promethean age, the greatest of all time. "Tertium non datur," there is no third, was their creed.

That Elizabeth, the chief feminine character in the drama, shares this belief need cause no surprise. Moreover, in her role is presented the same problem as in the man. In her soul also, there is a struggle between two different conceptions. In the boginning, she herself does not understand this, but when at last she does understand, her heart receives its death blow, a deep, incurable wound, through which she slowly bleeds to death.

The Tannhkuser drame, which without doubt contains a sort of poetically limned, spiritual portrait of the word and tone poet Wagner, occupies at the same time a peculiarly central position among his artistic productions. The dual erotic problem which he there unconsciously touched upon, the relation of the elemental and the romantic love to life, and their biological significance, he subsequently divided into two separate themes. Love as an elemental, destructive force of nature became the life problem in "Tristan and Isolde," while love as self-renunciatory romanticism gave the key-note to "Parsifal."

And through "Tannhkuser" Wagner was led to the point where, for the first and last time in his life, and without suspecting it, he found himself in the forbidden circle of the "great third," and cast a glance into that realm of tragedy which is at the same time genuinely Promethean and genuinely Germanic, the realm of Shakespeare. And the inner force which at that time guided him and clarified his vision, was perhaps his greatest, the force of humor.

Werecall the close connection between humor and Germanic individualism and the tragic conception of life, and in an instant we understand the psychology which looks upon humor as the most masculine of all attributes of the soul. Among erotics, whose sentimental. life demands a more feminine excitement of an elemental, unreflecting character, this attribute is seldom to be found. The ability to control the uncertain moods of life, half dark, half light, gloomy or gay, which is based on self-mastery, comes only after the passions are under subjection.

With Wagner true humor appears for the first time in his next to the last work. And the extent of his genius for erotic composition may best be seen in the fact that this work stands 
alone as cpposed to nine, or if "Siegfried" is not counted, eight other works in which the life problem is tragic-erotic.

The plan of this work, "The Meistersingers of Nuremberg," originated first as a counterpart to the external treatment of "Tannhliuser." Therefore, even here the central theme is love although the humorous conception and vigorous treatment never allow it to stand out prominently, while it is often confused with the wealth of joyous themes and motifs growing out of the fundamental problem.

This fundamental problem, which is not erotic, although it receives its solution through love, consists of the contradictory relations arising between the individual on the one hand, who is endowed with creative power, and on the other hand, a receptive company of people made up of various ages and of different social standing.

These people are designated, in the beginning, as the court of final appeal for determining the value of all true production. In the matter of art, Wagner thereby places the comprehension of the people alongside that of women-and at a stroke lays bare the secret of his soul. The erotic artist, in the first place, instinctively addressed himself to women and unconsciously sought those life problems which would most deeply interest them.

In this way also, he won youth to his side, the age when love appears as the only thing in life, and as its special wonder. And with woman and youth as his allies, he conquered the worldalthough not without a struggle. 